\title{
FAKTOR-FAKTOR YANG BERHUBUNGAN DENGAN KUALITAS KERJA PETUGAS PROGRAM PENCEGAHAN DAN PEMBERANTASAN (P2) DIARE
}

Mohammad Sadli*

\begin{abstract}
ABSTRAK
Penyakit diare di Kota Cirebon masih merupakan masalah dari tahun ke tahun. Penyakit ini selalu ada dan dapat menimbulkan kejadian luar biasa, dan menyebabkan kematian. Pola kematian menurut penyakit, penyebab kematian pasien kunjungan di puskesmas Kota Cirebon untuk semua golongan umur tidak ditemukan adanya angka kematian diare. Dari data laporan yang dilaporkan oleh seluruh Puskesmas angka kesakitan diare sebanyak 28648 penderita dengan golongan umur $<1$ Tahun : 4316 penderita, 1 - 4 Tahun : 8703 Penderita , >5 Tahun : 15196 penderita. Hal ini menunjukkan masih tingginya angka incident diare di Kota Cirebon. Tujuan penelitian ini adalah untuk mengetahui Gambaran faktor-faktor yang berhubungan dengan kualitas kerja petugas P2 Diare yang ada di puskesmas-puskesmas Kota Cirebon tahun 2015. Penelitian ini menggunakan desain cross sectional dengan pendekatan kuantitatif dengan jumlah populasi 37 dengan sampel 37 petugas yang tersebar di wilayah puskesmas Kota Cirebon. Pengumpulan data dilakukan dengan teknik wawancara terhadap ibu balita, menggunakan kuesioner. Analisis bivariat menggunakan uji T-test. Hasil Penelitian menunjukkan lebih dari setengah petugas diare puskesmas menunjukan kualitas kerja yang baik. Ada hubungan yang bermakna antara sarana yang tersedia dengan kualitas kerja petugas diare puskesmas, ada hubungan yang bermakna antara faktor kepemimpinan dengan kualitas kerja petugas diare puskesmas, tidak ada hubungan yang bermakna antara faktor pendidikan dengan kualitas petugas diare puskesmas. tidak ada hubungan antara faktor pelatihan dengan kualitas kerja petugas diare puskesmas, tidak ada hubungan antara faktor keterampilan dengan kualitas kerja petugas diare puskesmas, tidak ada hubungan antara faktor monitoring evaluasi dengan kualitas kerja petugas diare.

Kata Kunci : Kualitas Kerja, Petugas P2 Diare
\end{abstract}

\begin{abstract}
Diarrhea in Cirebon is still a problem from year to year. The disease is always there and can give rise to an extraordinary event, and cause death. The pattern of death by disease, the cause of death of patients in the clinic visit Cirebon city for all age groups did not reveal any mortality diarrhea. From the report data reported by all health centers diarrhea morbidity as much as 28648 patients by age group <1 Year: 4316 patients, 1-4 Year: 8703 patients,> 5 Year: 15196 patients. This shows the high level of incidents of diarrhea in the city of Cirebon. The purpose of this study was to determine the description of the factors associated with quality work P2 officers diarrhea in health centers Cirebon 2015. This study used cross sectional design with quantitative approach with a population of 37 with a sample of 37 officers spread across the region puskesmas Cirebon. The data collection was done by using interviews with mothers, using a questionnaire. The bivariate analysis using test T-test. Research shows more than half the officers diarrhea puskesmas showed good quality work, There was a significant association between the means available to the quality of the work attendant diarrhea puskesmasa, there was a significant association between the factors of leadership with the quality of the work attendant diarrhea clinic, there is no significant relationship between factor of quality education officer diarrhea clinic. there is no correlation between the quality of work training with diarrhea puskesmas officers, there was no correlation between the quality of work skills with diarrhea puskesmas officers, there was no correlation between monitoring and evaluation officer with quality work diarrhea.
\end{abstract}

Keywords : Quality of Work, Officer P2 Diarrhea 


\section{PENDAHULUAN}

Pembangunan Kesehatan merupakan salah satu upaya pembangunan nasional yang bertujuan untuk meningkatkan kesadaran dan kemampuan hidup sehat bagi setiap orang agar terwujud derajat Kesehatan masyarakat yang optimal, sebagaimana tercantum dalam UndangUndang RI nomor 23 tahun 1992 pasal 30 tentang Kesehatan yang berbunyi sebagai berikut ${ }^{1}$ : "Pemberantasan penyakit menular dilaksanakan dengan upaya penyuluhan, penyelidikan, pengebalan, menghilangkan sumber dan perantara penyakit, tindakan karanfina dengan upaya lain yang diperlukan".

Pendekatan upaya-upaya Kesehatan untuk meningkatkan derajat Kesehatan yang optimal pemerintah telah merubah kebijaksanaan pendekatan yang dipakai dengan lebih menitikberatkan upaya-upaya yang telah mengutamakan promotif dan preventif dengan tidak meninggalkan upaya kuratif dan rehabititatif. ${ }^{2}$

Penyakit Diare masih merupakan masalah kesehatan masyarakat di Indonesia, beberapa faktor yang menjadi penyebab timbulnya penyakit diare disebabkan oleh kuman melalui kontaminasi makanan/minuman yang tercemar tinja danlkontak langsung dengan penderita , sedangkan faktor-faktor lainya meliputi faktor penjamu dan faktor lingkungan. Gambaran secara keseluruhan angka insiden penyakit diare di Indonesia selama kurun waktu lima tahun dari tahun 2010 sampai tahun 2014 adalah: pada tahun 2010 sebesar 10,7 per 1000, pada tahun 20116,7 per 1000, tahun 2012 sebesar 10,6 per 1000, tahun 2013 sebesar 0,6 per 1000 dan tahun 2014 sebesar 5,8 per $1000 .^{2}$

Distribusi Frekuensi KLB dan kematian menurut jenis penyakit di Indonesia tahun 2013 bahwa telah terjadi 1068 kali KLB, Diare memiliki frekuensi kejadian yang paling tinggi (275 kali) dengan total jumlah kasus adalah 28530, jumlah kasus terbanyak adalah Diare (14045 kasus) dan jumlah kematian adalah 263 kematian dengan kematian tertinggi pada penyakit diare (93 kematian). ${ }^{2}$

Program pemberantasan penyakit menular mempunyai peranan dalam menurunkan angka kesakitan dan kematian. Tujuan tersebut dapat dicapai dengan penerapan teknologi kesehatan secara tepat oleh petugas-petugas Kesehatan yang didukung peran serta aktif dari masyarakat. $^{2}$

Penyakit diare di Kota Cirebon masih merupakan masalah dari tahun ke tahun. Penyakit ini selalu ada dan dapat menimbulkan kejadian luar biasa, dan menyebabkan kematian.

Pola kematian menurut penyakit, penyebab kematian pasien kunjungan di puskesmas Kota Cirebon untuk semua golongan umur tidak ditemukan adanya angka kematian diare. ${ }^{3}$

Dari data laporan yang dilaporkan oleh seluruh puskesmas angka kesakitan diare sebanyak 28648 penderita dengan go(ongan umur $<1$ Tahun : 4316 penderita, 1 - 4 Tahun : 8703 Penderita, > 5 Tahun : 15196 penderita, masih menunjukkan tingginya incident rate di Kota Cirebon. ${ }^{3}$

Berdasarkan data ketenagaan bahwa di setiap Puskesmas pelaksana Program P2 Diare dipegang oleh satu orang dengan kualifikasi pendidikan perawat kesehatan dan belum mendapat pelatihan, begitu juga dengan pelatihan kader belum dilaksanakan.

Sarana dan prasarana di tempat perawatan dan rawat jalan terdapat pojok URO tetapi belum semua puskesmas melaksanakannya begitu juga di tempat Puskesmas Pembantu dan Polindes., untuk kebutuhan oralit tidak sesuai dengan kebutuhan yang diperhitungkan sesuai dengan perkiraan target pelayanan penderita. Buku pedoman / petunjuk oprasional/bentuk terpadu lainnya belum ada edisi terbaru dan format/alat tulis kerja sebagai bahan administrasi dalam hal, pelaporan puskesmas mengadakan sendiri Begitu juga dukungan dana kurang berjalan. ${ }^{3}$ 
Tujuan penelitian ini untuk mengetahui faktor-faktor yang berhubungan dengan kualitas kerja petugas P2 Diare yang ada di puskesmas-puskesmas Kota Cirebon tahun 2015.

\section{METODE PENELITIAN}

Rancangan dalam penelitian ini adalah penelitian analitik deskriptif dengan menggunakan desain penelitian cross sectional yaitu mempelajari semua individu yang berada taraf umurnya dan titik waktu yang sama atau pendekatan yang sifatnya sesaat pada satu waktu dan tidak diikuti dalam kurun waktu tertentu. ${ }^{4}$ Populasi adalah semua petugas P2 Diare di 37 Puskesmas yang ada di Kota Cirebon. Besar sempel adalah sebesar 37 orang petugas P2 Diare di wilayah Dinas Kesehatan Kota Cirebon yang diambil secara keseluruhan. Lokasi penelitian dilaksanakan di puskesmas-puskesmas yang ada di Kota Cirebon. Teknik pengumpulan data menggunakan metoda wawancara dengan menggunakan kuesioner terhadap 37 responden petugas P2 Diare puskesmas di Kota Cirebon, dan pengamatan dilakukan secara langsung ke lapangan. Analisis univariat dengan menggunakan tabel distribusi frekuensi. Analisis Bivariat menggunakan uji statistik T-test independent dengan Keputusan sebagai berikut :

1) Pvalue $\leq \alpha$, Ho ditolak yang berarti ada hubungan yang bermakna, dengan tingkat kemaknaan $95 \%(\alpha=0,05)$

2) Pvalue $>\alpha$, Ho gagal ditolak yang berarti tidak terdapat hubungan yang bermakna, dengan tingkat kemaknaan $95 \%(\alpha=0,05)$

\section{HASIL PENELITIAN}

\section{Kualitas Kerja Petugas P2 Diare}

Hasil penelitian menunjukkan bahwa lebih dari setengah petugas Diare puskesmas memiliki kualitas kerja baik 23 responden $(62,2 \%)$.

\section{Pendidikan}

Hasil penelitian menunjukkan bahwa 35 orang $(94,6 \%)$ Berpendidikan SPK/AKPER dan 2 orang $(5,4 \%)$ berpendidikan S.Kp/SKM

\section{Umur}

Hasil penelitian menunjukkan bahwa mayoritas umur petugas di Pepuskesmas tergalong muda yaitu 31 responden $(83.8 \%)$.

\section{Pelatihan}

Hasil penelitian menunjukkan bahwa ternyata hampir semua petugas diare tidak pernah mendapatkan pelatihan diare 36 responden $(97,3 \%)$.

\section{Keterampilan}

Hasil penelitian menunjukkan bahwa lebih dari sebagian petugas diare Puskesmas Terampil dalam pengelolaan program Diare 23 responden $(62.2 \%)$.

\section{Sarana yang tersedia}

Hasil penelitian menunjukkan bahwa sebagian besar puskesmas di Kota Cirebon memiliki sarana pengelolaan program diare dengan lengkap 35 responden (94.6\%)

\section{Kepemimpinan}

Hasil penelitian menujukkan bahwa sebagian besar kepala Puskesmas adanya kepemimpinan terhadap petugas Diare puskesmas 19 responden $(51.4 \%)$. 


\section{Monitoring Evaluasi}

Hasil penelitian menunjukkan bahwa sebagian besar petugas Kabupaten melakukan monitoring kepada petugas Diare Puskesmas 22 responden $(59.5 \%)$.

\section{Hubungan antara Pendidikan, Pelatihan dengan Kulitas kerja}

Tabe1 1. Hubungan Faktor pendidikan, Pelatihan dengan Kualitas Kerja Petugas Diare

\begin{tabular}{llcc}
\hline Faktor & Kategori & Mean rank & Pvalue \\
\hline Pendidikan & SMU & 0 & 0.928 \\
& SPK/AKPER & 13.4 & \\
& SPPH/AKL & 0 & \\
& SPAG/AKZI & 0 & 0.100 \\
\hline Pelatihan & SKp/SKM & 13.5 & \\
& Sering & 0 & \\
& Pernah & 11.00 & \\
& Tidak pernah & 13.47 & \\
\hline
\end{tabular}

Dari tabel di atas menujukan bahwa dari hasil uji statistik diketahui Pvalue pendidikan 0.928 dan 0.100 untuk pelatihan dengan $\alpha=0.05$ maka pvalue $>\alpha$ menujukan bahwa kedua faktor tersebut tidak ada hubungan dengan kualitas kerja petugas diare Puskesmas.

\section{Hubungan antara Keterampilan, dan Monitoring Evaluasi dengan Kualitas Kerja}

Tabel 2. Hubungan Faktor Keterampilan, dan Monitoring Evaluasi dengan Kualitas Kerja

\begin{tabular}{llllc}
\hline Faktor & Kategori & Mean & SD & Pvalue \\
\hline Keterampilan & Terampil & 13.52 & 1.37 & 0,568 \\
& Tdk. Terampil & 13.21 & 1.67 & 0,121 \\
\hline Monev & Ada & 13.10 & 1.44 & \\
& Tdk. Ada & 13.87 & 1.45 &
\end{tabular}

Dari tabel di atas menujukan bahwa pvalue Keterampilan 0.568, dan Monev 0.121, ternyata untuk keterampilan dan monev pvalue $>\alpha(0.05)$, maka tidak terdapat hubungan faktor keterampiian dan monev dengan kualitas kerja petugas Diare puskesmas. sedangkan untuk keterampilan walaupun tidak terdapat hubungan yang erat namun ada kecendrungan dalam memberikan pengaruh terhadap kuaiitas kerja hal ini dapat dilihat dari adanya kenaikan rata-rata sebesar 0.31 poin.

\section{Hubungan antara sarana, dan kepemimpinan dengan Kualitas Kerja}

Tabel 3. Hubungan Faktor sarana, dan kepemimpinan dengan Kualitas Kerja

\begin{tabular}{llllc}
\hline Faktor & Kategori & Mean & SD & Pvalue \\
\hline \multirow{2}{*}{ Sarana } & Terampil & 13.37 & 1.52 & 0.019 \\
\cline { 2 - 4 } & Tdk. Terampil & 14.00 & 0.00 & \\
\hline \multirow{2}{*}{ Kepemimpinan } & Ada & 13.89 & 1.37 & 0.037 \\
\cline { 2 - 4 } & Tdk. Ada & 12.89 & 1.45 & \\
\hline
\end{tabular}

Dari tabel di atas menunjukan bahwa pvalue sarana yang tersedia 0.019, Kepemimpinan 0.037 ternyata untuk Sarana dan kepemimpinan pvalue $<\alpha(0.05)$ maka 
terdapat hubungan antara faktor sarana dan kepemimpinan dengan kualitas kerja petugas diare Puskesmas.

\section{PEMBAHASAN}

\section{Hubungan Pendidikan dengan Kualitas Kerja}

Pada penelitian ini sebagian besar responden berpendidikan SPK/AKPER yaitu 94.6\% dan sisanya berpendidikan SKp/ SKM.Melalui uji statistik anova dengan tingkat kemaknaan $95 \%$ dan $\alpha=0,05$ didapat pvalue $>\alpha(0,05)$ terlihat tidak terdapat hubungan yang bermakna antara pendidikan dengan kualitas kerja petugas diare puskesmas, dengan demikian hipotesis tentang ada hubungan variabel pendidikan dengan kualitas kerja petugas diare puskesmas tidak terbukti, hasil ini sejalan dengan penelitian Pebriani (2014) yang menyatakan tidak ada hubungan variabel pendidikan terhadap kualitas kerja pembimbing praktek lapangan Akper.

\section{Hubungan Pelatihan dengan Kualitas Kerja}

Pelatihan merupakan bagian dari suatu proses pendidikan yang bertujuan untuk meningkatkan kemampuan atau keterampilan khusus seseorang atau kelompok orang. ${ }^{5}$ Pelatihan juga dapat merupakan cara untuk membekali tenaga kerja yang tidak mempunyai pendidikan formal sesuai tugasnya, sehingga meningkatkan kualitas kerjanya, dalam penelitian ini diharapkan agar seseorang lebih mudah melaksanakan tugasnya.

Hasil penelitian ini menunjukan bahwa sebagian besar responden tidak mendapatkan pelatihan, melaui uji statistik anova dengan tingkat kemaknaan $95 \% \alpha(0,05)$ di dapatkan $\mathrm{P}=$ 0.100 dengan demikian pvalue $>\alpha(0,05)$ artinya tidak terdapat hubungan yang bermakna antara variabel pelatihan dengan kualitas kerja petugas diare puskesmas. Hal tersebut berbeda dengan penelitian sebelumnya, misal Ilias (1998) menyatakan ada hubungan pelatihan saat tugas dengan kinerja dokter PTT di puskesmas. Akan tetapi penelitian yang dilakukan Basjuni (2001) sejalan dengan penelitian ini yaitu tidak ada hubungan antara pelatihan dengan kinerja petugas TB paru.

Tidak terdapat hubungan pelatihan dengan kualitas kerja ini kemungkinan disebabkan oleh materi dan metoda yang diberikan pada saat pelatihan belum sesuai dan bermanfaat bagi petugas.

\section{Hubungan Keterampilan dengan Kualitas Kerja}

Hasil penelitian menunjukan bahwa 23 responden $(62,2 \%)$ terampil dalam melaksanakan tugas penanggulangan diare, Kartzdan Mintzberg, 1984 berpendapat mengenai keterampilan teknis yaitu kemampuan menggunakan pengetahuan, alat, pmsedur, teknik dan metoda suatu bidang tertentu, dari data yang ada mayoritas responden adalah terampil.

Hasil uji statistik dengan menggunakan T-Test indefendent pada penelitian ini di dapat pvalue $=0.568$ dengan $\alpha(0,45)$ maka pvalue $>\alpha(0,05)$ yang artinya tidak terdapat hubungan antara keterampilan dengan kualitas kerja petugas diare puskesmas, akan tetapi ada kecendrungan dalam memberikan pengaruh terhadap kualitas kerja dengan dilihat adanya kenaikan rata-rata sebesar 0.31 poin.Hal ini bertolak belakang dengan penelitian sebelumnya A. Zaenudin (2004) yang menyatakan ada hubungan bermakna antara keterampilan dengan kualitas kerja petugas TB paru.

\section{Hubungan Sarana yang tersedia dengan Kualitas Kerja}

Sumber daya merupakan bagian atau elemen dari input, keberadaan sumber daya dalam suatu organisasi merupakan hal yang paling pokak sekaligus sebagai modal dasar untuk berfungsinya suatu organisasi. Puskesmas sebagai salah satu organisasi fungsional yang 
menghasilkan jasa pelayanan Kesehatan, memiliki sumberdaya yang mencakup ketenagaan, dana, sarana dan metoda. ${ }^{6}$

Hasil penelitian menunjukan bahwa responden yang memiliki sarana lengkap sebesar 94,6\%. Dari hasil uju statistik menggunakan T-test Indefendent didapatkan pvalue $=0.019$ dengan $\alpha(0,05)$ maka pvalue $<\alpha(0,05)$ yang artinya terdapat hubungan yang bermakna antara sarana yang tersedia dengan kualitas kerja petugas diare puskesmas. Hal ini sesuai dengan penelitian A. Zaenudin, 2004 yang menyatakan bahwa ada hubungan yang bermakna antara sarana dengan kualitas kerja petyugas TB paru.

\section{Hubungan Kepemimpinan dengan Kualitas Kerja}

Kepemimpinan adalah kempampuan untuk mempengaruhi suatu kelompok ke arah tercapainya tujuan. Dari hasil analisis univariat didapat dari 37 responden lebih banyak menilai kepemimpinan oleh kepala puskesmas baik yaitu $51.4 \%$, dari hasil uji statistik T-Test indefendent terdapat hubungan yang bermakna antara kepemimpinan dengan kualitas kerja petugas diare puskesmas dengan pvalue $=0.037 \alpha(0,05)$ (pvalue $<\alpha(0,05)$. Hasil tersebut sesuai dengan Gibson, bahwa ada hubungan antara faktor kepemimpinan dengan Kinerja.

Dengan demikian hipotesis tentang adanya hubungan antara faktor kepemimpinan dengan kualitas kerja petugas diare terbukti bermakna secara statistik.

\section{Hubungan Monitoring evaluasi dengan Kualitas Kerja}

Monitoring evaluasi merupakan suatu kegiatan pembinaan, bimbingan dan pengawasan oleh pengelola program / proyek terhadap pelaksanaan program di tingkat administrative yang lebih rendah, tujuan dari monev adalah mengatasi masalah yang dihadapi petugas dilapangan untuk meningkatkan pengetahuan dan keterampilan petugas yang di monev dalam rangka memotivasi kerja petugas. ${ }^{2}$ Dalam penelitian ini $59.5 \%$ mendapatkan monitoring evaluasi, dari hasil uji statistik didapatkan tidak ada hubungan yang bermakna antara faktor monitoring evaluasi dengan kualitas kerja petugas diare puskesmas dengan pvalue $=0.121$ dan $\alpha$ yang digunakan 0.05 (pvalue $>\alpha 0,05$ ).

Hal ini tidak sesuai dengan penelitian Rumisis (2003) bahwa monev bermanfaat berpeluang 5.192 kali meningkatkan kinerja bidan di desa. Pada penelitian ini hipotesis yang diduga ada hubungan yang bermakna antara faktor monitoring evaluasi dengan kualitas kerja petugas diare tidak terbukti.

\section{SIMPULAN}

1. Lebih dari setengah petugas diare puskesmas menunjukan kualitas kerja yang baik.

2. Ada hubungan yang bermakna antara sarana yang tersedia dengan kualitas kerja petugas diare puskesmas. Dengan pvalue yang didapat sebesar 0.019 dengan $\alpha(0,05)$

3. Ada hubungan yang bermakna antara faktor kepemimpinan dengan kualitas kerja petugas diare puskesmas. Hal ini disebabkan di Indonesia khususnya di Kota Cirebon sifat paternalistic masih kuat, kepala puskesmas sangat berpengauh terhadap sikap dan tingkah laku bawahannya, keteladanan seorang pimpinan masih dijunjung tinggi.

4. Tidak ada hubungan yang bermakna antara faktor pendidikan dengan kualitas petugas diare puskesmas. Hal ini disebabkan karena pendidikan yang baik belum tentu menghasilkan kualitas kerja yang baik jika tidak didasari oleh niat dan motivasi kerja yang tinggi.

5. Tidak ada hubungan antara faktor pelatihan dengan kualitas kerja petugas diare puskesmas, hat ini disebabkan bahwa pelatihan yang diberikan oleh jenjang yang lebih tinggi kemungkinan belum sesuai dan bermanfaat bagi petugas diare atau pun juga metoda yang diberikan pada pelatihan belum sesuai dengan peserta pelatihan. 
6. Tidak ada hubungan antara faktor keterampilan dengan kualitas kerja petugas diare puskesmas, hat ini disebabkan karena ketrampilan dalam hat penguasaan pengetauan dan prosedur yang ditetapkan belum maksimal dikarenakan sarana, lokasi dan prasarana belum mendukung.

7. Tidak ada hubungan antara faktor monitoring evaluasi dengan kualitas kerja petugas diare, hat ini disebabkan bahwa orang Indonesia khususnya di Kota Cirebon jika tidak sering melaksanakan monev oleh tingkat yang lebih tinggi maka tugas yang dilaksanakan akan selalu malas-malasan dalam arti tidak termotivasi.

\section{SARAN}

1. Bagi Dinas Kesehatan

1) Mengadakan pendidikan pelatihan bagi petugas diare puskesmas dengan materi mengenai manajemen mutu terpadu dalam menjalankan organisasi

2) Melakukan pembinaan melalui monitoring evaluasi kualitas kerja pada petugas diare puskesmas.

3) Menyediakan sarana dan prasarana bagi puskesmas yang belum lengkap.

2. Bagi UPTD Puskemas

1) Kepala Puskesmas hendak nya pada saat ini melakukan dan menerapkan kepemimpinan dengan prinsip dan fokus terhadap pelanggan baik pelanggan internal maupun ekternal

2) Puskesmas mulai mengoptimalkan segala sumber daya yang dimiliki dengan menjaga mutu pelayanan Kesehatan dengan melakukan paradigma sehat, pemeriksaan penunjang, diagnosa, terapi, perawatan atau konsultasi dan rujukan serta pencatatan dan pelaporan dengan mengacu pada standard dan prosedur yang ditetapkan secara propesional.

3. Bagi Petugas Diare Puskesmas

Melakukan perbaikan kualitas kerja secara terus menerus dengan bertahap yang menggunakan sistem PDCA (plan, Do, Check, Act) dengan membuat suatu perencanaan yang baik dan pelaksanaan yang terpadu serta evaluasi secara terus menerus yang diintegrasikan dengan Lintas program atau Lintas Sektoral.

\section{DAFTAR PUSTAKA}

1. Anonim. Undang-undang No. 23 tentang Kesehatan,Jakarta:Departemen Kesehatan $\mathrm{RI} ; 1992$

2. Anonim. Buku data surveilan epidemiologi, Jakarta: Departemen Kesehatan RI;2014

3. Anonim. Laporan Tahunan Dinas Kesehatan Kota Cirebon:Dinkes Kota Cirebon;2014

4. Sugiono. Metoda penelitian administrasi, edisi ke 6, Bandung, CV. Alfabeta;1999

5. Soekidjo Notoatmodjo. Pendidikan dan perilaku kesehatan. Rineka Cipta:Jakarta;2003

6. Aditama Chandra Yoga. Manajemen administrasi Rumah Sakit. Jakarta: UI Press;2000 